\title{
Yakın anlamlı sözcüklerin semantiği: Japoncadaki yıkım-tahrip anlamlı eylemlerin karşılaştırmalı analizi
}

\section{Metin BALPINAR'}

\begin{abstract}
APA: Balpınar, M. (2020). Yakın anlamlı sözcüklerin semantiği: Japoncadaki yıkım-tahrip anlamlı eylemlerin karşılaştırmalı analizi. RumeliDE Dil ve Edebiyat Araştırmaları Dergisi, (20), 626-641. DOI: $10.29000 /$ rumelide.792267.
\end{abstract}

$\ddot{\mathbf{O} z}$

Japon dili yakın anlamlı sözcükler bakımından zengin bir dildir. Mevcut Japonca-Türkçe sözlüklerin Japonca yakın anlamlı sözcüklerin anlamlarını açıklamada yetersiz kalması, Japonca öğrenen ve anadili Türkçe olan öğrenciler için söz konusu sözcükler arasındaki anlam farklarının kavranmasını zorlaştırmaktadır. Bu çalışmada, yakın anlamlı sözcüklerin birbirine benzer ve birbirinden farklı anlamsal özelliklerinin nasıl belirleneceği, bu sözcüklerin öntip anlamları ile çoklu anlamları arasındaki karşılıklı ilişkilerin nasıl tesis edileceği hususları, yıkım-tahrip anlamı taşıyan壊す 'kowasu', 砕く 'kudaku’ ve 割る ‘waru' yakın anlamlı eylemleri aracılığıyla bilişsel anlambilim kuramı çerçevesinde tartışlacaktır. Çalışmada şu hususlara vurgu yapılacaktır: (i) 壊す 'kowasu' sözcüğünde metonimi, 砕く 'kudaku' sözcügüüde metonimi ile sinekdok ve 割る 'waru' sözcüğünde metafor, metonimi ve sinekdok temelli anlamsal genişlemeler gözlemlenmektedir, (ii) söz konusu anlamsal genişlemeler her bir sözcüğün öntip anlamı kullanılarak açıklanabilmektedir, (iii) 砕く 'kudaku' sözcüğünün öntip anlamı 割る 'waru’ sözcüğünün öntip anlamını kapsar niteliktedir, (iv) 砕く 'kudaku’ ve 割る 'waru' eylemlerinin işlevsel parçalardan oluşmuş nesneleri belirten sözcüklerle de kullanılabilmeleri, bu eylemlerin öntip anlamlarını 壊す 'kowasu’ sözcüğünün anlam alanına yaklaştırmaktadır, (v) sinekdok temelli anlamsal genişlemenin varlı̆̆ı, bir eyleme ait taslak-öntip anlam ve taslak-ikincil anlam ilişkileriyle sınırlı olmayıp, öntip anlam ve ikincil anlam arasındaki karşılıklı ilişkileri de kapsamaktadır.

Anahtar kelimeler: Japonca, yıkım-tahrip anlamlı eylemler, yakın anlamlılı, öntip anlam, anlamsal genişleme

\section{Semantics of near-synonyms: A comparative analysis of the verbs meaning destruction in Japanese}

\begin{abstract}
Japanese is a language which is rich in near-synonyms. The incompetence of current JapaneseTurkish dictionaries in explaining the meanings of near-synonyms makes it difficult for the Turkish speaking students who learn Japanese to grasp the semantic differences between those synonyms. In this study, the issue how to determine similar and distinctive semantic properties of near-synonyms, and the issue how to establish mutual relationships between prototypical senses and polysemous senses of those synonyms are discussed through the near-synonymic Japanese verbs 壊す 'kowasu', 砕く 'kudaku' ve 割る within the framework of the cognitive theory of semantics. The following points are emphasized in the study: (i) there are semantic extensions based on metonymy in the word 壊す 'kowasu', metonymy and synecdoche in 砕く 'kudaku', metaphor, metonymy and synecdoche in 割
\end{abstract}

$1 \quad$ Dr. Öğr. Üyesi, Burdur Mehmet Akif Ersoy Üniversitesi, Fen Edebiyat Fakültesi, Doğu Dilleri ve Edebiyatları Bölümü (Burdur, Türkiye), mbalpinar@mehmetakif.edu.tr, ORCID ID: 000o-0003-0998-2963 [Makale kayıt tarihi: 07.07.2020kabul tarihi: 20.09.2020; DOI: 10.29000/rumelide.792267] 
る 'waru', (ii) the semantic extensions in question can be explained using the prototypical sense of each verbs, (iii) the prototypical sense of 砕く 'kudaku' involves the prototypical sense of 割る 'waru', (iv) the fact that 砕く 'kudaku' and 割る 'waru' can also be used with words that refer to the objects formed by functional parts closes the prototypes of 砕く 'kudaku' and 割る 'waru' to the semantic field of 壊す 'kowasu', and (v) the existence of synecdoche-based semantic extension is not limited to the relations such as schema-prototypical sense and schema-secondary meaning regarding a verb, but also includes the mutual relations between prototypical sense and secondary meaning.

Keywords: Japanese, verbs meaning destruction, near-synonymy, prototypical sense, semantic extension

\section{Giriş}

Türkçe alan yazında sinonim ya da eş anlaml sözcük olarak adlandırılan synonym terimini, Bussmann (1996, s. 1164), dar anlamda bir sözcükle aynı anlama sahip olan başka bir sözcük ya da ifade, geniş anlamda ise örtüşen anlamlara sahip sözcükler olarak tanımlanmaktadır. Bu tür sözcükler arasındaki anlamsal ilişkiyi ifade eden eş anlamlılı (synonymy) kavramıyla ilgili olarak Bloomfield (1933), fonetik yapısı farklı olan formların anlamlarının aynı olamayacağına işaret etmektedir. Hatiboğlu (1970), anlam eşitliğinin göreceli olduğunu, matematiksel bir eşitlikten bahsedilemeyeceğini ve dolayısıyla eş anlamlı sayılan sözcüklerin eşdeğer olmadıklarını savunmaktadır. Palmer (1981), eş anlamlı gibi görünen sözcüklerin esasen farklı olduklarını ve aynı anlama sahip sözcüklerin bir dilde hayatta kalmasının mümkün görünmediğini dile getirmektedir. Benzer biçimde, Tekin (1997) de sözcükler arasında anlamkullanım farkı olduğunu örneklerle göstermekte ve bir dilde eş anlamlı sözcüklerin olmadığını vurgulamaktadır. Aksan (2000, 2004), bir kavramın sadece bir sözcükle karşılandığını ve dilde aynı anlama gelen iki öğenin bulunamayacağını vurgulamakta ve eş anlamlı sözcüklerin esasen yakın anlaml sözcükler olduğunu ileri sürmektedir. Machida ve Momiyama (2002), anlamları tamamıla aynı olduğu düşünülen Japonca sözcüklerin (同義語 'dōgigo') aslında eşdeğerli sözcükler olmadığını, her sözcüğün bir diğerinde bulunmayan anlamsal özellikler barındırdığını örneklerle açıklamakta ve bu tür sözcükleri benzer anlamlı sözcükler (類義語 'ruigigo') olarak nitelendirmektedir. 2, 3

Yabancı dil eğitiminde, yakın anlamlı sözcükler arasındaki anlam farklarının öğrenciler tarafından doğru kavranması, onların sözcük dağarcıklarının geliştirilmesi kadar önemli bir husustur. Bu açıdan, doğru sözcük edinimi, ses ve biçim bilgisi kadar, ancak bu tür sözcüklere ait anlam özelliklerinin bilinmesiyle mümkündür. Japon dili yakın anlamlı sözcükler bakımından zengin bir dildir. Mevcut Japonca-Türkçe sözlükler incelendiğinde, söz konusu materyalin, Japonca yakın anlamlı sözcükler arasındaki anlam farklarını açıklamada yetersiz kaldığı görülmektedir. Aşağıdaki Japonca sözcüklere ve Türkçe açılamalarına bir göz atarak duruma yakından bakalım.

Kowasu: Bozmak, kırmak, yıkmak (Takeuchi, 1996, s. 482)

Bozmak, kırmak, hastalanmak (Yamashita, 1992, s. 111)

Bozmak, kırmak, yıkmak, tahrip etmek (Demirci, 1999, s. 312)

\footnotetext{
2 Bu açıdan bakıldığında, sinonim kavramını 'örtüşen anlamlara sahip sözcükler’ olarak tanımlamak ve bu kavramı da (yazarın da dâhil olduğu anonim hakem görüşüne göre) Türkçede yakın anlamlı sözcük kavramıyla karşılamak yerinde olacaktır. Türkçede eş-yakın anlamlılık sorunsalıyla ilgili çalışmalar için bkz. Tekin (1997), Ersoylu (2001), Aksan (2004), Sarı (2011), Duman (2015), Gündoğdu (2019).

3 Japonca alan yazında, Türkçedekine benzer biçimde, synonym (İng.) teriminin karşıllğı olarak 同義語 'dōgigo'/同意語 'dōigo' (fonetik formları farklı, anlamları aynı olan sözcükler) ve 類義語 'ruigigo' (fonetik formları farklı, anlamları benzer olan sözcükler) terimleri kullanılmaktadır.
} 
Kırmak, bozmak (Çankaya, 1996, s. 97)

Kudaku: Ezmek, kırmak (Takeuchi, 1996, s. 478)

Kırmak, parçalamak, ezmek (Demirci, 1999, s. 313)

Vurup kırmak, parçalamak (Çankaya, 1996, s. 98)

Waru : Yarmak, kırmak, bölmek (Takeuchi, 1996, s. 529)

Bölmek, ayırmak, kırmak (Yamashita, 1992, s. 225)

Bölmek, dağıtmak, ayırmak, kırmak, yarmak (Demirci, 1999, s. 656)

Bölmek, yarmak, kırmak (Çankaya, 1996, s. 182)

Yukarıdaki Japonca yakın anlamlı sözcükler ve bunların Türkçe karşılıkları incelendiğinde, (a) her bir Japonca sözcüğe ilişkin Türkçe anlamın, yakın anlamlı farklı sözcükler kullanılarak verilmeye çalışıldığı, (b) söz konusu Japonca sözcükleri tanımlamak için aynı sözcüğün (örn. kırmak) tekrarlanarak kullanıldığı, (c) sadece Türkçe anlam karşılıklarından hareketle, Japonca sözcüklerin gerçek anlamlarını tespit etmenin ya da Japonca sözcükler arasındaki anlamsal ayrımı yapmanın pek mümkün olmadığı ve (ç) bazı Japonca sözcüklerin sözlük içeriğine dahi dâhil edilmediği (örn. Yamashita (1992) tarafından yazılmış olan sözlükte kudaku sözcüğünün bulunmadı̆̆ı) görülmektedir. Japonca öğrenen-öğreten kişiler için temel danışma kaynaklarından biri olan Japonca-Türkçe sözlüklerde görülen bu tür sorunların varlığı, bu kişiler için yakın anlamlı sözcükler arasındaki anlam farklarının kavranmasını ve öğretilmesini zorlaştırmaktadır.

Bu çalışmada, yakın anlamlı sözcüklerin birbirine benzer ve birbirinden farklı anlamsal özelliklerinin nasıl belirleneceği, bu sözcüklerin öntip anlamları ile çoklu anlamları arasındaki karşılıklı ilişkilerin nasıl tesis edileceği hususları, yıkım-tahrip anlamı taşıyan ve aşağıda bir örneği verilen (bkz. örnek 1) 壊 す 'kowasu', 砕く 'kudaku' ve 割る 'waru' Japonca yakın anlamlı eylemleri aracılığıyla tartışılacaktır. Bu hâliyle, çalışma, sadece yukarıda bahsedilen mevcut sorunlara sistematik bir değerlendirmeyle katkı sağlamayı değil, aynı zamanda yakın anlamlılık olgusunun çok yönlü doğasına, kısmen de olsa, ışık tutmayı da amaçlamaktadır.

(1)アリさんは 田中さん の ランプを\{壊した/砕いた/割った\}。

Ari-san wa Tanaka-san no ranpu wo \{kowashita/kudaita/watta\}.

Ari-san KONU Tanaka-san TAM lamba BEL $\{$ bozdu/parçaladı/kırdı\}.4

Ali, Tanaka'nın lambasını $\{$ bozdu/parçaladı/kırdı $\} .5$

Çalışmada, kowasu-kudaku-waru sözcüklerinin anlambilimsel özelliklerini belirlemek amaciyla, bu sözcükleri içeren çeşitli kullanımlara bilişsel yaklaşımlı anlambilimsel analiz uygulanacaktır. ${ }^{6}$ Analiz için gereken veriler (kowasu-kudaku-waru sözcüklerinin gerçek anlamları ile gerçek anlamları dışındaki anlamları barındıran tümceler ve ifadeler), Japonca sözcüklerin çeşitli kullanımlarını bir araya getiren ve mevcut en geniş kapsamlı Japonca-Japonca sözlüklerden olan Kōjien (広辞苑), Meikyō Kokugo Jiten (明鏡国語辞典), Sūpā Daijirin (スーパー大辞林) ve Japonca-İngilizce-Japonca

$4 \quad$ Kisaltmalar: KONU-konu belirtici (topic); TAM-tamlayan durumu (genitive case); BEL-belirtme durumu (accusative).

5 (1)'deki tümcede kowasu-kudaku-waru sözcüklerinin Türkçe çevirileri, sadece, ana dili Türkçe olan okurların Japonca tümceyi anlamlandırmasına yardımcı olmak amacıyla verilmiştir. Söz konusu Türkçe çeviri sözcükler, Japonca sözcüklerin birebir anlam karşllıkları olarak düşünülmemelidir.

6 Bilissel Anlambilim (Cognitive Semantics), dil kullanıcısının sahip olduğu birtakım bilișsel (örn. kıyaslama, aynı şeyi farkl bakış açısından ele alma, aynı şeyi farklı derinlikte/incelikte ele alma vb.) mekanizmalarla, dile ilişkin kavramsal (anlamsal) yapıya ve kavram oluşturma süreçlerine açılamaya getirmeye çalışan anlambilim kuramı olarak tanımlanabilir. Kuram, kavramlaşma sürecinde, dil kullanıcısının zamana ya da mekâna ilişkin deneyimine vurgu yapar. Bilişsel anlambilim alanına ilişin kuramsal altyapı ve bu alanda düzenlenmiş̧ çalışmalar için Jackendoff (1983), Talmy (2000), Machida ve Momiyama (2002), Croft ve Cruse (2004), Geeraerts (2006), Langacker (2009)'a başvurulabilir. 
sözlüklerden olan Jiniasu Waei-Eiwa Jiten (ジニアス和英・英和辞典) içinden alınacaktır. Analiz aşamasında, ilk olarak, kowasu-kudaku-waru'nun öntip anlamını (prototypical sense) belirlemek amacıyla, bu sözcükleri içeren ifadelerin [ \pm etki] ve [ \pm değişsim] değerleri irdelenecektir (Kısım 2.1-4-1).7 Ardından, kowasu-kudaku-waru sözcüklerinin öntip anlamları tespit edilerek bunlar dışında kalan kullanımlara ait anlamsal genişlemelere dikkat çekilecektir (Kısım 2.2-4-2). Son olarak, kowasukudaku-waru sözcüklerine ait, öntip anlamlar arasındaki ilişkiler (Bölüm 5) ve çoklu anlamlar arasındaki ilişkiler (Bölüm 6) üzerinde durulacaktır.

\section{2. 壊す ‘Kowasu’ sözcüğünde çokanlamlılık ve çoklu anlam analizi}

$\mathrm{Bu}$ bölümde, kowasu sözcüğünün farklı kullanımları ele alınarak bunlara ait [ ${ }^{2}$ etki] ve [ \pm değişim] değerleri tespit edilecektir (Kısım 2.1). Ayrıca, bu değerler dikkate alınarak kowasu sözcüğünün öntip anlamı belirlenecek ve öntip anlam dışında kalan kullanımlarda ortaya çıkan anlamsal genişlemelere ışık tutulacaktır (Kısım 2.2).

\section{1 壊す ‘Kowasu’ sözcüğünde çokanlamlılık}

(1)-(4)'deki tümceler incelendiğinde, Japonca kowasu sözcüğünün birden fazla anlama (çokanlamlılığa) sahip olduğu görülebilir.

(1) 古い家屋を壊す (Sūpā Daijirin (Matsumura, 1999))

Furui kaoku wo kowasu

'Eski bir evi yıkmak'8

(2) 時計をとり落として壊す (Sūpā Daijirin)

Tokei wo toriotoshite kowasu

'Saati (elinden) düşürüp bozmak'

（3）飲みすぎて体を壊す (Meikyō Kokugo Jiten (Kitahara, 2010))

Nomisugite karada wo kowasu

'Çok fazla içip beden sağlı̆̆ını bozmak'

(4) 彼女はパーティーの雾囲気を壊す (Jiniasu Waei-Eiwa Jiten, (Konichi ve Minami, 2006))

Kanojo ha pātī no funiki wo kowasu

'O (kız) parti ortamını bozar'

(1)'deki kowasu sözcü̆üu, kılıcının (agent) güç kullanarak nesne (kaoku 'ev') üzerinde bir tahrip etkisi oluşturduğunu ve bunun sonucunda da söz konusu nesnenin fiziksel bütünlüğünde bir bozulma meydana geldiğini ifade etmektedir. Burada, kılıcı tarafından eyleme konu olan nesneye uygulanan gücün varlığı ya da yokluğu [ \pm etki], etki sonucu söz konusu nesne üzerinde gözlemlenebilen fizikseldurumsal farkın varlığı ya da yokluğu [ \pm değişim] ile gösterilirse (1)'deki kowasu eyleminin [+etki] ve [+değişim] değerlerinden oluşan bir anlam bütününe sahip olduğunu söylemek mümkün olur. ${ }^{9}$ Benzer

Söz konusu [ \pm etki] ve [ \pm değişim] değerlerine Kısım 2.1'de ve öntip anlam kavramına da Kısım 2.2'de değinilecektir. Japonca tümcelerin Türkçe çevirileri yazar tarafindan yapılmıştır. Japonca ifadelerin transkripsiyonunda Hepburn yöntemi kullanılmıștır.

Kinsui ve Imani (2008), bir eylemin tipik anlamının belirlenmesi aşamasında, varlıkların veya nesnelerin olaylar içinde neden, kllıcı/eden, alet-araç, nesne ve sonuç gibi anlamsal roller (semantic role) üstlendiğini rapor etmektedir. Japoncadaki yıkım-tahrip anlamlı eylemlerin incelendiği bu çalışmada neden, kılıcı, araç ve nesneye ilişkin anlamsal roller [etki] değeriyle, [değişim] ise sonuç rolüyle ilişkilendirilerek konunun daha basit ve anlaşılır kılınması amaçlanmıştır. 
biçimde, örnek (2)'de de kılıcı, saat üzerinde tahrip edici bir etkiye neden olmakta ve bunun sonucu olarak da saatin fiziksel bütünlüğünde ve işlevlerinde kayba sebebiyet vermektedir. Bu durum, (2)'deki kowasu sözcüğünün de [+etki] [+değişim] değerlerini taşıdığını bize göstermektedir.

Diğer taraftan (1) ve (2)'den farklı olarak, örnek (3) ve (4)'de, kowasu eylemine konu olan karada 'vücut (sağllk)' ve funiki 'ortam' üzerinde fiziksel bir etkide bulunulmamasına karşın, bunlar üzerinde birtakım gözle görülebilir birtakım durumsal değişimlerin oluştuğundan (ya da oluşabileceğinden) söz etmek mümkündür. Örneğin (3)'de, birinin çok miktarda içki içerek sindirim sistemi zorlaması, reflü, kusma ve karında şişlik gibi bir takım belirtilerin ortaya çıkmasına neden olabilmekte, bu da içki içme öncesi ve sonrası arasında durumsal bir değişime işaret etmektedir. Aynı şekilde, örnek (4)'te de, parti ortamının kılıcı (kanojo 'o (kız)') tarafindan bozulmasının öncesi ve sonrasında bir takım durumsal değişimler meydana gelebileceğini söylemek mümkündür (örn. parti ortamında kılıcının neden olduğu bir tartışma öncesi herkes dans ederken, tartışma sonrası herkesin kavga etmesi gibi). Eğer bu tespitlerimiz doğruysa, (3) ve (4)'deki kowasu sözcüklerinin her birinin anlam yapısının '[-etki] [+değişim]' ş̧eklinde olması beklenebilir.

Yukarıdaki tespitler ışığında, örnek (1)-(4)'deki kowasu sözcüğüne ait anlam özelliklerini şu şekilde özetlemek mümkündür:

(1') Furui kaoku wo kowasu $\rightarrow$ [+etki] [+değişim]

$\left(2^{\prime}\right)$ Tokei wo toriotoshite kowasu $\rightarrow$ [+etki] [+değişim]

(3') Nomisugite karada wo kowasu $\rightarrow$ [-etki] [+değişim]

(4') Kanojo ha pātī no funiki wo kowasu $\rightarrow$ [-etki] [+değişim]

(1')-(4') bize, (1) ve (2)'deki kowasu eyleminin hem etki hem de değişim değerlerine sahipken, (3) ve (4)'deki kowasu sözcüğünün ise sadece değişim değerine sahip olduğunu göstermektedir. Bu durum, kowasu'nun öntip anlamının (prototypical sense) (1) ve (2)'deki tümcelerde aranması gerekliliğine işaret etmektedir; zira öntip, bir ulama ait tüm özellikleri içermelidir.

\section{2 壊す ‘Kowasu’ sözcüğünün öntip anlamı ve çoklu anlam analizi}

Türkçeye öntip olarak çevrilen İngilizce prototype sözcügü, Yunanca prótos 'ilk' ve typos 'şekil' anlamlarına gelen sözcüklerin bileşiminden oluşmaktadır ve anlambilimde bir ulama ait tipik özelliklerin bütününü ifade etmek için kullanılmaktadır (Bussmann, 1996, s. 963). Uçar (2009, s. 13), öntipi ‘ulam içerisinde temsil niteliği en yüksek örnek' olarak tanımlar. Öntipi temel alan ulam ise, tipik üye(ler)den ve çeşitli düzeylerde düşük tipik özellikler gösteren diğer üyelerden oluşmaktadır. Örneğin, güvercin, penguen, tavuk ve devekuşu gibi hayvanlar kuş ulamı içinde değerlendirilebilecek canlılar olmalarına karşın, uçabilme yeteneğine sahip olmaları açısından bakıldığında, bunlardan sadece güvercinin kuş ulamının öntipi olduğu söylenebilir. Bu bağlamda, yıkım-tahrip anlamına sahip bir eylemin öntipinin belirlenmesinde, bir önceki kısımda ele alınan, söz konusu eylemin anlamına ilişkin [+etki] ve [+değişim] değerlerinin her ikisinin de bulunması gerektiğini söylememiz mümkündür. Japonca kowasu eylemi özelinde düşünüldüğünde, bu durumun sadece (1) ve (2)'deki tümceleri kapsamakta olduğu görülebilir (bkz. 1'-4').

Japonca-Japonca sözlüklerden biri olan Meikyō Kokugo Jiten (明鏡国語辞典) 'de kowasu sözcüğünün birincil anlamı şu şekilde verilmektedir: カを加えて、物の形を損なわせる (güç uygulayarak, nesnenin şekline zarar vermek). Başka bir Japonca-Japonca sözlük olan Sūpā Daijirin (スーパー大辞林)'de de 
benzer bir ifadeye rastlanmaktadır: 物体にカを加えて、もとの形を崩したりばらばらにしたりする (nesneye güç uygulayarak, asıl şeklini tahrip etmek, parçalarına ayırmak). İlk bakışta, bu açıklamaların herbirinin [+etki] ve [+değişim] değerlerine sahip olduğunu ve bunların kowasu sözcüğünün öntip anlam tespiti için yeterli olduğu düşünülebilir. Ancak, (1) ve (2)'deki örneklere yakından bakıldığında, nesneye güç uygulanması sonucu söz konusu nesnenin hem dış görünüşünde (fiziksel tahribat) hem de işlevinde değişiklik (işlevsel kayıp) meydana geldiği söylenebilir. Bu durum, ayrıca, tümce (1) ve (2)'deki kowasu eylemine konu olan nesnelerin ( $k a o k u$ 'ev' ve tokei 'saat') işlevsel parçalardan oluşmuş bir bütün olduğu gerçeğini de bizlere göstermektedir. Bu tespitler ışığında, kowasu sözcüğünün öntip anlamı şu şekilde yazılabilir:

(5) Kowasu: İşlevsel parçalardan oluşmuş bir bütüne güç uygulayarak onun fiziksel yapısına ve işlevine zarar vermek

Bu noktada cevaplanması gereken soru, (5)'deki tanımdan yararlanarak, (3) ve (4)'deki kullanımların nasıl açıklanabileceği sorusudur. Bu sorunun cevabı, metonimi (düzdeğişmece) temelli anlamsal gelişmede gizlidir. Metonimi, 'benzetme amacı gütmeksizin tümce ya da dizimde bulunan öğeler arasında bütün-parça, neden-sonuç, genel-özel, somut-soyut ilişkiler kurulması yoluyla oluşan değişmece türü’ olarak tanımlanmaktadır (İmer vd. 2011, s. 106)..10 Diğer değişmece türleri (metafor, sinekdok) gibi, metonimi de yeni anlamların ortaya çıkışını destekleyen bilişsel anlambilim ilkelerinden biridir. Bu ilkenin işleyişini, (3) ve (4)'deki örneklerde de görmemiz mümkündür. (3)'deki karada wo kowasu 'bedenini bozmak' eylem öbeği, 'beden (ya da ona ait kısımlar) üzerinde birtakım travmatik etkiler yaratmak suretiyle, yapısal bütünlüğünü bozarak normal işlevini yapamaz hâle getirmek' doğrudan (literal) anlamıyla, 'hastalanmak' deyimsel anlamına sahip olup, bu iki anlam zaman ekseni üzerinde neden-sonuç ilişkisiyle birbirine bağlanmıştır. ${ }^{11} \mathrm{Bu}$ ilişki, doğrudan anlamı kullanarak deyimsel anlamı ifade edebilmeyi mümkün kılmaktadır. Benzer biçimde, (4)'deki pātī no funiki wo kowasu 'parti ortamını bozmak' eylem öbeği, 'parti ortamında toplu durumda bulunan nesnelerin düzenini karıştırmak' doğrudan anlamıyla, 'iyi bir durumu kötü hâle getirmek' deyimsel anlamına sahiptir. Burada, ilk anlamdaki fiziksel durumla ikinci anlamdaki psikolojik durumun zamansal olarak art arda ortaya çıkışı temel alınarak ikinci anlamın oluşturulduğu görülmektedir.

Yukarıdaki tartışmayı şu şekilde özetlemek mümkündür:

(1') Furui kaoku wo kowasu

$\left(2^{\prime \prime}\right)$ Tokei wo toriotoshite kowasu

(3") Nomisugite karada wo kowasu

(4") Kanojo wa pātī no funiki wo kowasu

$$
\begin{aligned}
& \rightarrow[+ \text { etki }][+ \text { değişim }] \rightarrow \text { öntip anlam } \\
& \rightarrow[+ \text { etki }][+ \text { değişim }] \rightarrow \text { öntip anlam } \\
& \rightarrow[\text {-etki }][+ \text { değişim }] \rightarrow \text { metonimi } \\
& \rightarrow[\text {-etki }][+ \text { değişim }] \rightarrow \text { metonimi }
\end{aligned}
$$

\section{3. 砕く 'Kudaku' sözcüğünde çokanlamlılık ve çoklu anlam analizi}

Bölüm 3’de, kudaku eylemine ait farklı kullanımlar ele alınarak bunlara ait [ \pm etki] ve [ \pm değişim] değerleri tespit edilecektir (Kısım 3.1). Ayrıca, bu değerler göz önünde bulundurularak kudaku

10 Bir büyüğü içip bitirmek ifadesi metonimi temelli anlamsal genişlemeye örnek olarak verilebilir. Bu ifadedeki büyük sözcüğüyle asıl anlatılmak istenen, 75 cl'lik sisseyi ölçüt alarak 75 cl'lik sise ile mekânsal olarak yakınlık iliskisi (bütünparça ilişkisi) içinde olan nesneyi, yani içkiyi (rakı), göstermektir. Metonimiyle ilgili Japonca örnekler için bkz. Machida ve Momiyama (2002, ss. 76-81 ve p. 132-141).

11 (3)'deki 体を壊す'karada wo kowasu' eylem öbeğinin anlamına 体 'karada' (beden/vücut) sözcüğü açısından bakıldığında, bu sözcüğ̈̈n beden denilen nesneyi değil beden sağh̆̆̆na ilişkin durumu ifade ettiği söylenebilir. Bu bağlamda değerlendirildiğinde de, (3)'deki karada wo kowasu öbeğinin metonimi temelli anlam genişlemesinin bir ürünü olduğu söylemek mümkündür. Çünkü (3)'de beden sözcüğü referans alınarak, beden ve beden sağhğı (ya da beden sağ lığına ilişkin durum) arasında somut-soyut bir anlam ilişkisi kurulmak istenmektedir. 
eyleminin öntip anlamı belirlenecek ve öntip anlam kapsamı dışında kalan kullanımlara ilişkin anlamsal genişlemelere ışık tutulmaya çalışılacaktır (Kısım 3.2).

\section{1 砕く'Kudaku' sözcüğünde çokanlamlılık}

Örnek (6)-(10)'daki Japonca ifadelere bir göz atalım.

(6) アイスピックで氷を砕く (Meikyō Kokugo Jiten)

Aisupikku de kōri wo kudaku

'Buz kırıcıyla buzu parçalamak'

（7）育児に心を砕く (Meikyō Kokugo Jiten)

Ikuji ni kokoro wo kudaku

'Çocuk bakımı için çaba harcamak'

(8) 店の再建に身を砕く (Kōjien, (Shinmura, 2008))

Mise no saiken ni mi wo kudaku

'Dükkânın yeniden inşası için çok zahmet/zorluk çekmek'

(9) 法律の条文を砕いて説明する (Sūpā Daijirin)

Hōritsu no jōbun wo kudaite setsumei suru

'Kanun maddelerini anlaşılır biçimde açıklamak'

Kudaku sözcüğü, (6)'daki tümcede, söz konusu nesneye (kōri 'buz') darbe uygulayarak onu ufak parçalara ayırmak anlamında kullanılmıştır. Bu durumu, Kısım 2.1'de bahsi geçen [ \pm etki] ve [ \pm değisşim] özelliklerini kullanarak şu şekilde ifade etmek mümkündür: [+etki] [+değişim]. Başka bir deyişle, (6)'daki kudaku, bir alet yardımıyla buza bir darbe/basınç uygulanması bakımından [+etki] değerine ve bu eylem sonrasında buzun fiziksel bütünlüğünü kaybetmesi bakımından da [+değişim] değerine sahiptir. (7)-(9)'daki örnekler incelendiğinde ise, kowasu eyleminin belirtili nesnesi durumunda olan (7)'deki kokoro 'kalp/yürek/gönül', (8)'deki mi 'beden/vücut/kendi' ve (9)'daki hōritsu no jōbun 'kanun maddesi' üzerinde kılıcı tarafından fiziksel bir etki oluşturulmadığı görülebilir. Buna karşın, (7)-(9)'daki kudaku eyleminden önceki durumla sonraki durum karşılaştırıldığında ikisi arasında bir değişimden bahsetmek mümkündür. (7)'de öncesinde isteksizce yapılan çocuk bakımı işi, sonra verilen bir kararla daha istekli ve itinalı yapılır hâle gelecektir. Örnek (8)'da, dükkânın yeniden inşası için pek çaba sarf edilmeyen durumdan epey çaba sarf edilir duruma bir geçiş görülecektir. (9)'da anlaşllır biçimde açıklanmayan kanun maddeleri anlaşılır biçimde açıklanmaya başlanacaktır. Eğer, bu tespitlerimiz doğruysa, (7)-(9)'daki kudaku eylemlerinin etki ve değişim değeri [-etki] [+değişim] şeklinde olacaktır.

Yukarıdaki tespitleri şu şekilde özetlemek mümkündür:

(6') Aisupikku de kōri wo kudaku $\rightarrow$ [+etki] [+değişim]

(7') Ikuji ni kokoro wo kudaku $\rightarrow$ [-etki] [+değişim]

$\left(8^{\prime}\right)$ Mise no saiken ni mi wo kudaku $\rightarrow$ [-etki] [+değişim]

$\left(9^{\prime}\right)$ Hōritsu no jōbun wo kudaite setsumei suru $\rightarrow$ [-etki] [+değişim] 


\section{2 砕く'Kudaku' sözcüğünün öntip anlamı ve çoklu anlam analizi}

Kudaku sözcüğ̈̈nün birincil anlamı, Meikyō Kokugo Jiten’de ‘固まっている物にカを加えて、細かい破 片にする’ (sert bir nesneye güç uygulayarak, kü̧̈ük parçalara ayırmak), Sūpā Daïirin'de de ‘固まってい るものを、打撃や圧カを加えて細かい破片にする (sert bir nesneyi, darbe ve basinç uygulayarak küçük parçalara ayırmak)' olarak açıklanmıştır. Kudaku eyleminin analizi için toplanan örnek tümceler incelendiğinde bu eylemden doğrudan etkilenen $a d ı n$ gösterdiği cismin (işlevsel parçalardan oluşup oluşmadıklarına bakılmaksızın) genel olarak sert cisimler oldukları söylemek mümkündür. Bu durum, bu tür sert nesnelerin küçük parçalara ayrılabilmeleri için (özel durumlar haricinde, örn. kılıcının süper güçlü olması) bir alet kullanmasını gerekliliğine işaret etmektedir. Öyleyse, kudaku sözcüğünün öntip anlamını şu şekilde yazmamız mümkündür:

(10) Kudaku: Bir alet yardımıyla sert bir nesneye darbe ya da basınç uygulayarak onu küçük parçalara ayırmak

Şu ana kadarki tespitlerimiz, (6)'daki kudaku sözcüğünün (10)'daki öntip anlama sahip olduğunu bize göstermektedir. Burada cevaplanması gereken soru şudur: Kudaku sözcüğünün (6)'daki kullanımıyla (7)-(9)'daki kullanımları arasında anlambilimsel açıdan nasıl bir ilişki vardır? Örnek (7) için bu sorunun cevabı sinekdok (synecdoche) ve metonimi temelli anlam değişmecelerinde gizlidir. Sinekdok, ‘よりー 般的な意味を持つ形式を用いて、より特殊な意味を表す、あるいは逆に、より特殊な意味を持つ形式 を用いて、より一般的な意味を表すという比喻 (anlamsal olarak daha genel bir dilsel şekli kullanarak daha özel bir anlamı ya da anlamsal olarak daha dar bir dilsel şekli kullanarak daha genel bir anlamı ifade eden değişmece)' türü olarak tanımlanmaktadır (Machida ve Momiyama, 2002, s. 69). (7)'deki kokoro wo kudaku ifadesi, 'güç uygulayarak kalbi parçalara ayırmak' gerçek anlamıyla '(bir işin üstesinden gelebilmek için) ızdırap çekmek' ikincil anlamına sahiptir. Burada, güç uygulayarak bir kişinin kalbini parçalara ayırmasının, o kişinin ızdırap çekmesinin bir yolu olduğu düşünüldüğünde, (7)'de daha dar (özel) olan gerçek anlam kullanılarak daha geniş (genel) olan ikincil anlamın ifade edilmeye çalışıldığı görülebilir. Bu açıdan bakıldığında, (7)'deki ifadenin sinekdok temelli anlamsal genişlemenin bir ürünü olduğunu söylemek mümkündür. Diğer taraftan, gerçek anlamı, ikincil anlamın nedeni (ve ikincil anlamı da gerçek anlamın sonucu) olarak değerlendirdiğimizde ise bu iki anlam arasında metonomi temelli bir anlamsal genişleme olduğunu söylemek mümkündür. Benzer biçimde, örnek (8) ve (9)'daki kudaku sözcüğ̈̈nün anlamı da metonimi temelli anlam değişmesi olarak analiz edilebilir. (8)'deki mi wo kudaku ifadesi, 'kendini/bedenini parçalamak' gerçek anlamıla 'çok zorluk/acı/üzüntü çekmek' ikincil anlamlarına sahip olup, bu iki anlamın neden-sonuç ilişkisiyle birbirine bağlı olduğu düşünülebilir. Başka bir deyişle, kendini/bedenini parçalamanın doğal bir sonucu olarak (fiziksel ve psikolojik olarak) çok zorluk/acı/üzüntü çekmek durumu söz konusudur. (9)'daki kudaku eylemi (te-çekimi kudaite şeklindedir), 'kanun maddelerindeki uzun tümceleri daha kısa tümcelere ayırmak' gerçek anlamıyla, 'kanun maddelerindeki uzun ve zor tümceleri daha anlaşılır hâle getirmek' ikincil anlamlarına sahiptir. Bu örnekte, bu iki anlam arasında bir araç-amaç ilişkisinin varlığından söz etmek mümkündür. Başka bir ifadeyle, 'kanun maddelerindeki uzun ve zor tümceleri daha anlaşılır hâle getirmek' amaçsa bunun bir yolu 'kanun maddelerindeki uzun tümceleri daha kısa tümcelere ayırmak' olacaktır.

Yukarıdaki tartışma ve Kısım 3.1'deki tespitler dikkate alındığında, kudaku sözcüğünün sahip olduğu etki ve değişim değerleriyle, bu sözcükte görülen anlamsal değişimleri şu şekilde özetlemek mümkündür: 
(6") Aisupikku de kōri wo kudaku $\rightarrow$ [+etki] [+değişim] $\rightarrow$ öntip anlam

$\left(7^{\prime \prime}\right)$ Ikuji ni kokoro wo kudaku $\rightarrow$ [-etki] [+değişim] $\rightarrow$ sinekdok, metonimi

$\left(8^{\prime \prime}\right)$ Mise no saiken ni mi wo kudaku $\rightarrow$ [-etki] [+değişim] $\rightarrow$ metonimi

$\left(9^{\prime \prime}\right)$ Hōritsu no jōbun wo kudaite setsumei suru $\rightarrow$ [-etki] [+değişim] $\rightarrow$ metonimi

\section{4. 割る ‘Waru’ Sözcüğünde Çokanlamlılık ve Çoklu Anlam Analizi}

Bu bölümde, waru eylemine ait çeşitli kullanımlar üzerinde durularak bunlara ait [ \pm etki] ve [ \pm değiş̧im] değerleri belirlenecektir (Kısım 4.1). Ayrıca, bu [ \pm etki] ve [ \pm değişim] değerlerinden yararlanarak kudaku eyleminin öntip anlamı tespit edilecek ve öntip anlam kapsamı dışında kalan kullanımların da öntiple olan yakın ilişkisine dikkat çekilecektir (Kısım 4.2).

\section{1 割る ‘Waru' Sözcüğüünde Çokanlamlılık}

Aşağıdaki örnekleri inceleyelim.

（11）石をぶつけてガラスを割る (Meikyō Kokugo Jiten)

Ishi wo butsukete garasu wo waru

'Taşı çarparak camı kırmak'

(12) 薪を割る (Jiniasu Waei-Eiwa Jiten)

Maki wo waru

'Odunu kırmak'

(13) 衝突して唇を割る (Meikyō Kokugo Jiten)

Shōtotsu shite kuchibiru wo waru

'Çarparak dudağını yarmak

(14) 行列に割ってはいる (Meikyō Kokugo Jiten)

Gyōretsu ni watte hairu

'Yararak kuyruğa/sıraya girmek'

(15) 腹を割って話しあおう(Meikyō Kokugo Jiten)

Hara wo watte hanashiaō

'Açıkça konuşalım'

(16) 川ロで船を割る (Sūpā Daijirin)

Kawaguchi de fune wo waru

'Başarıya ramak kala başarısızlığa uğramak'

(17) ニ人の仲を割る (Meikyō Kokugo Jiten)

Futari no naka wo waru

'İki kişinin arasını açmak’

(18) 15を5で割れば3になる (Jiniasu Waei-Eiwa Jiten)

15 wo 5 de wareba 3 ni naru

'15'i 3'e bölersek 3 olur' 
Örnek (11) ve (12)'deki waru sözcüğü, sert yapıya sahip bir nesneye (11'de garasu 'cam' ve 12'de maki 'odun') güç uygulayarak onu birkaç parçaya ayırmak anlamında kullanılmıştır. Bu durumu, [tetki] ve [ \pm değişim] özelliklerini kullanarak [+etki] [+değişim] biçiminde ifade etmemiz mümkündür. Diğer taraftan, (13) ve (14)'deki waru sözcüğü de, kuchibiru 'dudak' ve gyōretsu 'kuyruk’a bir darbe/basınç uygulanması bakımından [+etki] değerine ve bu eylem sonrasında dudak ve kuyruğun fiziksel bütünlüğünü kaybetmesi bakımından da [+değişim] değerine sahip olduğu düşünülebilir. Ancak, güç uygulanması sonucu, kuchibiru 'dudak' yaralanmış fakat birkaç parçaya ayrılmamış ve gyōretsu 'kuyruk/sıra' da birkaç parçaya ayrılarak o şekilde kalmamıştır. Bu açıdan bakıldığında, (13) ve (14)'deki waru sözcüğünün [-değişim] değerinde olduğu görülebilir. (15)-(18)'deki örneklerde ise, (11)-(14)'den farklı olarak, eyleme konu olan nesnelere kılıcı tarafından fiziksel bir kuvvet uygulanmamasına karşın, waru eyleminden önceki durumla sonraki durum karşılaştırıldığında söz konusu nesneler için bir durumsal değişimden bahsetmek mümkün olabilmektedir. (15)'de, konuşucu, o ana kadar kendine saklamış olduğu bir gerçeği ya da konuyu, hara wo waru eylemine karar vermesiyle birlikte onu dinleyici ile paylaşacaktır. (16)'de, her şeyin yolunda gittiği bir durumdan başarısızlıkla sonuçlanacağı bir duruma doğru değişim gözlenecektir (örn. açık denizde sorunsuzca seyrederken tam nehir ağzına gelindiğinde gemiyi kazaya uğratmak gibi). (17)'da, waru eyleminden önce söz konusu iki kişi iyi ve yakın bir dostluk ilişkisi yürütmekteyken waru eylemiyle birlikte bu durum bozulacaktır. (18)'da, söz konusu matematik işlemi yapılmadan önceki sayısal değerle sonraki sayısal değer arasında belirgin bir durumsal fark olacağı açıktır. Eğer bu tespitlerimiz doğruysa, (11)-(18)'deki waru eyleminin etki ve değişim değerlerini aşağıdaki gibi özetlememiz mümkündür.
(11') Ishi wo butsukete garasu wo waru
$\rightarrow[+$ etki] [+değişim $]$
(12') Maki wo waru
$\rightarrow[+$ etki] [+değişim $]$
(13') Shōtotsu shite kuchibiru wo waru
$\rightarrow$ [+etki] [-değişim]
(14') Gyōretsu ni watte hairu
$\rightarrow$ [+etki] [-değişim]
(15') Hara wo watte hanashiaō
$\rightarrow$ [-etki] [+değişim]
(16') Kawaguchi de fune wo waru
$\rightarrow$ [-etki] [+değişim]
(17') Futari no naka wo waru
$\rightarrow$ [-etki] [+değişim]
(18') 15 wo 5 de wareba 3 ni naru
$\rightarrow$ [-etki] [+değişim]

\section{2 割る ‘Waru' sözcüğünün öntip anlamı ve çoklu anlam analizi}

Waru sözcüğünün birincil anlamını, Meikyō Kokugo Jiten ‘力を加えて固いものをいくつかの部分に分 け離す’ (güç uygulayarak sert bir nesneyi birkaç parçaya bölüp ayırmak), Sūpā Daïirin ‘カを加えて、 いくつかの部分に分けるようにする (güç uygulayarak birkaç parçaya bölme işini yapmak)' olarak açıklamaktadır. Yukarıda bir araya getirdiğimiz veriler incelendiğinde, waru eyleminden doğrudan etkilenen cismin, kudaku eyleminden etkilenen cisme göre, daha büyük parçalara ayrıldığını söylemek mümkündür; zira waru sözcüğü, miktar bildiren belirteçlerle birlikte kullanılabilmektedir (örn. maki wo futatsu ni waru 'odunu iki parçaya/ikiye bölmek'). O hâlde, bu bulgular doğrultusunda waru sözcüğünün anlamını şu şekilde yeniden yazmak mümkündür:

(19) Waru: Güç uygulayarak sert bir nesneyi birkaç parçaya ayırmak

Kısım 2.2'de, yıkım-tahrip anlamına sahip bir eylemin öntip anlamının belirlenmesinde, söz konusu eylemin hem [+etki] hem de [+değişim] değerini taşıması gerektiğini söylemiştik. (11')-(18')'deki etki ve değişim dağılımı incelendiğinde, sadece (11')-(12')'deki waru sözcüklerinin bu değerlere sahip olduğu 
görülebilmektedir. Bu gözlemimiz doğruysa, (11/11')-(12/12')'deki tümcelerin de öntip anlam barındırdı ğını söylemek mümkündür.

Öyleyse, (19)'daki öntip anlamdan yararlanarak (13)-(18)'deki waru sözcüğünün anlamını nasıl açılayabiliriz? (13)-(14)'deki tümcelere bir göz atalım. Bu tümcelerde, waru sözcügünün geçtiği ifadeleri metafor temelli anlamsal genişlemeler olarak görmek mümkündür. Metafor, iki olay/kavram arasındaki benzerliği (ya da ortak özelliği) temel alarak, bir olayı/kavramı ifade eden sözcüğü kullanarak diğer olayı/kavramı ifade etme biçimidir. (13)'deki kuchibiru wo waru ifadesinin gerçek (doğrudan) anlamı 'güç uygulayarak dudă̆ parçalara ayırmak' ile ikincil anlamı 'dudak dokusu üzerinde yarık açmak' arasında 'güç uygulayarak bir şeyin yapısal bütünlüğüne zarar vermek' ortak anlamı vardır. Benzer biçimde, (14)'deki gyōretsu wo waru 'kuyruğu/sırayı yarmak' ifadesi de 'güç uygulayarak kuyruğu/sırayı iki parçaya (parçalara) ayırmak' gerçek anlamı ile 'sağa ve sola ayırarak (geçilebilecek genişlikte) aralık açmak' ikincil anlamlarına sahiptir ve bu iki anlam, (13)'deki waru'da olduğu gibi, 'güç uygulayarak bir şeyin yapısal bütünlüğüne zarar vermek' ortak anlamıyla birbirine bağlanmıştır. Bu durum, (13)-(14)'deki waru'ya ait gerçek ve ikincil anlamlar arasındaki ilişkinin metafor temelli olduğunu bize göstermektedir. Diğer taraftan, (15) ve (17)'de metonimi, (16)'da hem metonimi hem de metafor temelli anlam genişlemeleri gözlenmektedir. Metonimi, daha önce Kısım 2.2'de bahsettiğimiz gibi, gerçek ve ikincil anlamın neden-sonuç ilişkisiyle birbirine bağlı olmasının sonucu oluşabileceği gibi, bu iki anlamın zamansal olarak da birbirini takip etmesi sonucu da ortaya çlkabilmektedir. (15)'deki hara wo waru ifadesinin gerçek ve ikincil anlamları da birbirini zamansal olarak takip eden olaylar olarak görülebilir. Yani, (15)'de 'karnını kesip (açarak) parçalamak' gerçek anlamını müteakiben 'hiçbir şeyi saklamadan içindekini göstermek' ikincil anlamını ortaya çıkmaktadır. ${ }^{12}$ (16)'daki kawaguchi de fune wo waru deyimsel ifadesi, 'uzun deniz yolculuğunu sorunsuz tamamlamanın ardından koya yaklaşırken gemiyi parçalamak' gerçek anlamıyla, 'başarıya ramak kala çuvallamak' ikincil anlamlarını barındırmaktadır. Burada, bu iki anlamın 'bir şeyin olmasına çok az kala başarısız olmak' ortak anlamıyla birbirine bağlandığı göz önünde bulundurulduğunda, (16)'daki ifadenin metafor temelli bir anlamsal genişlemenin ürünü olduğu söylenebilir. Diğer taraftan, gerçek anlam bir neden ve ikincil anlam da bunun bir sonucu olarak ele aldığında, (16)'daki ifade metonimi temelli anlam genişlemesi olarak yorumlanabilmektedir. (17)'deki metomini temelli anlam genişlemesinin (15)'deki genişlemeden farkı, gerçek ve ikincil anlam arasındaki neden-sonuç ilişkinin ters yönde kurulmuş olmasıdır. Yani, (17)'de waru sözcüğünü içeren ifadeye ilişkin ikincil anlam 'iki kişi arasındaki dostluğu/ilişkiyi bozmak' bir neden, gerçek anlam 'güç uygulamak suretiyle iki (ya da daha fazla) kişi arasındaki fiziksel mesafeyi açmak' ise bu nedene bağlı bir sonuçtur. (18)'deki tümcede sinekdok temelli anlam genişlemeleri göze çarpmaktadır. (18)'daki 15 wo waru ifadesi, '15 eşit parçadan oluşmuş bir bütünü birkaç parçaya ayırmak' gerçek anlamıyla, '15 eşit parçadan oluşmuş bir bütünü 5’erli parçalardan oluşmuş gruplara ayırmak' ikincil anlamına sahiptir. Bu açıdan bakıldığında, ikincil anlamın, gerçek anlamın biri çeşidi olduğunu söylemek mümkündür. Başka bir deyişle, gerçek anlam, ikincil anlama göre daha kapsayıcı bir anlamsal içeriğe sahiptir.

\footnotetext{
12 Burada, (15)'deki tümceyle ilgili üzerinde durulması gereken bir diğer husus da, hara 'karın' sözcüğ̈nün hara wo waru bağlamı içinde metafor temelli anlam genişlemesi gösterdiğidir. Mide ve bağırsaklar gibi iç organlar koruyan/saklayan vücut kısmı anlamına gelen hara 'karın' sözcüğü, (15)'de açığa vurulmadan içte saklanan düşünce/duygu/sır anlamında kullanılmıştır. Bu iki anlam arasında, önemli şeylerin saklandığı/korunduğu yer ortak anlamı olduğunu dikkate aldığımızda, (15)'de hara sözcüğü kullanılarak metafor yapıldığını söylemek mümkündür. Çünkü metafor, iki olay/kavram arasındaki benzerliği temel alarak, bir olayı/kavramı ifade eden sözcüğü kullanarak diğer olayı/kavramı ifade etme biçimidir.
} 
Yukarıdaki tespitlerimizi şu şekilde özetlememiz mümkündür:

$\begin{array}{ll}\left(11^{\prime \prime}\right) \text { Ishi wo butsukete garasu wo waru } & \rightarrow \text { [+etki] [+değişim] } \rightarrow \text { öntip anlam } \\ \left(12^{\prime \prime}\right) \text { Maki wo waru } & \rightarrow[+ \text { etki] [+değişim] } \rightarrow \text { öntip anlam } \\ \left(13^{\prime \prime}\right) \text { Shōtotsu shite kuchibiru wo waru } & \rightarrow[+ \text { etki] [-değişim] } \rightarrow \text { metafor } \\ \left(14^{\prime \prime}\right) \text { Gyōretsu ni watte hairu } & \rightarrow \text { [+etki] [-değişim] } \rightarrow \text { metafor } \\ \left(15^{\prime \prime}\right) \text { Hara wo watte hanashiau } & \rightarrow[\text {-etki] [+değişim }] \rightarrow \text { metonimi } \\ \left(16^{\prime \prime}\right) \text { Kawaguchi de fune wo waru } & \rightarrow[\text {-etki] [+değişim] } \rightarrow \text { metonimi, metafor } \\ \left(17^{\prime \prime}\right) \text { Futari no naka wo waru } & \rightarrow \text { [-etki] [+değişim] } \rightarrow \text { metonimi } \\ \left(18^{\prime \prime}\right) 15 \text { wo } 5 \text { de } \text { wareba } 3 \text { ni naru } & \rightarrow[\text {-etki] }[+ \text { değişim }] \rightarrow \text { sinekdok }\end{array}$

\section{5. Öntip anlamları bakımından Kowasu-Kudaku-Waru arasındaki karşılıklı ilişki}

Kısım 2.2'de kowasu, 3.2'de kudaku ve 4.2'de de waru sözcüklerinin öntip anlamları belirlendi ve bu öntip anlamlardan yararlanarak herbir sözcükdeki anlam genişlemelerine ışık tutulmaya çalışldı. Bu bölümde, kowasu-kudaku-waru sözcüklerinin öntip anlamları arasındaki karşılıklı ilişkilere dikkat çekilecektir. Önce, Kısım 2.2-4.2'de üzerinde durduğumuz kowasu-kudaku-waru sözcüklerinin öntip anlamlarına tekrar bir göz atalım.

(20 (=5)) Kowasu: İşlevsel parçalardan oluşmuş bir bütüne güç uygulayarak onun fiziksel yapısına ve işlevine zarar vermek

(21 (=10)) Kudaku: Bir alet yardımıyla sert bir nesneye darbe ya da basınç uygulayarak onu küçük parçalara ayırmak

(22 (=19)) Waru: Güç uygulayarak sert bir nesneyi birkaç parçaya ayırmak

(20)-(22) dikkatle incelendiğinde, waru sözcüğünün anlamıla kudaku sözcügünün anlamı arasında $x$ bir y'dir ilişkisi (' $x$ is a y' relation) olduğu görülebilir. Yani, waru eylemi, kudaku eyleminin bir türü olarak değerlendirilebilir; zira bir nesneye güç uygulayarak onu birkaç parçaya ayırmak, aynı nesneyi küçük parçalara ayırmanın ya da bölmenin bir başka yoludur. Bu açıdan bakıldığında, kudaku'nun, waru'yu içine alan/kapsayıcı (generic) bir anlama sahip olduğu söylenebilir. Diğer taraftan, kudakuwaru ile kowasu sözcükleri arasında bu tarz bir kapsayıcı ilişkinin bulunduğunu söylemek güçtür; zira bir nesneyi küçük parçalara/birkaç parçaya ayırmak her zaman söz konusu nesnenin işlevine zarar vermeyeceği gibi (bkz. örnek 12), bir nesnenin işlevine zarar vermek de her zaman onun küçük parçalara/birkaç parçaya ayrılacağı anlamına gelmeyebilir (örn. elektromanyetik güç kullanarak elektronik bir cismin işleyişini bozmak gibi). Bu nedenle, kudaku-waru ile kowasu arasındaki öntip anlam ilişkisi, söz konusu eylemin kendinden çok eyleme konu olan nesnenin özellikleriyle ilintili görünmektedir. Örneğin, kowasu'da, eyleme konu olan nesne her zaman işlevsel parçalardan oluşmuş bir bütündür. Buna karşın, kudaku-waru'da, eyleme konu olan nesneler işlevsel parçalardan oluşmuş karmaşık yapılar olabileceği gibi (bkz. örnek 23-24), işlevsel parçalar barındırmayan basit nesneler de olabilir (bkz. örnek 6, 11, 12).

(23) 携帯電話の砕ける音が聞こえた。

Keitai denwa no kudakeru oto ga kikoeta.

'Cep telefonunun parçalanma sesini duydu(m).'

(24) 刀で携帯電話を真っニつに割った。

Katana de keitai denwa wo mapputatsu ni watta. 
'Katanayla cep telefonunu tam iki parçaya böldü(m).'

Bu bulgular ışığında, kowasu-kudaku-waru sözcükleri arasındaki öntip anlam ilişkisini aşağıdaki gibi şematize etmemiz mümkündür.

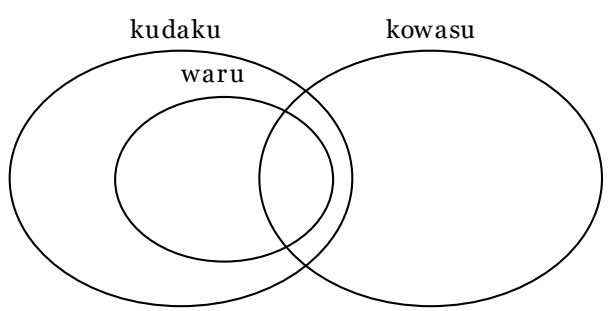

Şekil 1. Öntip anlamları bakımından kowasu-kudaku-waru sözcükleri arasındaki karşılıklı ilişki

Şekil 1'deki kowasu-kudaku-waru sözcüklere ait anlam alanlarının kesişimi olan bölgeyle anlatılmak istenen şudur: Kudaku-waru eylemlerine konu olan nesne işlevsel parçalardan oluşmuş bir bütünse (örn. örnek 23-24'deki cep telefonu gibi), o zaman bu eylemler de, tıpkı kowasu eyleminde olduğu gibi, işlev kaybı anlamı barındırabilmektedir. Bu kesişim alanı dışında kalan ve kudaku-waru sözcüklerine ait olan bölgeyse sadece işlevsel olmayan nesneleri eylem konusu yapmaktadır. Diğer taraftan, söz konusu kesişim alanı içi ve dışı ayrımına bakılmaksızın, kowasu'ya ait tüm alan, fiziksel tahribat sonucu ortaya çıkan işlev kaybı anlamına gelmektedir. Bu açıdan bakıldığında, Şekil 1'deki kesişim alanının, kudaku-waru ve kowasu öntip anlam alanlarının birbirine eşit oranlı yaklaşmasının bir sonucu değil, aksine kudaku-waru sözcüklerinin anlamının kowasu sözcügüne tek taraflı yaklaşmasının sonucu olarak ortaya çıkan bir alan olduğunu söylemek mümkündür.

\section{6. Çoklu anlamlar arasındaki karşılıkı iliş̧ki}

Kısım 2.2-4.2'de, kowasu-kudaku-waru eylemlerine ait çoklu anlamlar üzerinde durduk. Bu bölümde, bir eyleme ait çoklu anlamlar arasındaki karşılıklı ilişkilere ışık tutmaya çalışacă̆ız. Bu amaçla, metafor, metonimi ve sinekdok temelli anlamsal genişlemelerin her üçünün de görüldüğü waru eylemine ait verileri kullanarak tartışmayı şekillendirelim. Önce, örnek (13)-(14) ve (16)'daki metafor temelli anlamsal genişlemelere tekrar bir göz atalım. (13)'de kuchibiru wo waru ifadesinin gerçek anlamının 'güç uygulayarak dudağı parçalara ayırmak' ve ikincil anlamının da 'dudak dokusu üzerinde yarık açmak' olduğunu, (14)'de gyōretsu wo waru ifadesinin gerçek anlamının 'güç uygulayarak kuyruğu/sırayı iki parçaya (parçalara) ayırmak' ve ikincil anlamının da 'sağa ve sola ayırarak (geçilebilecek geniş̧likte) aralık açmak' olduğunu ve bu gerçek ve ikincil anlamların 'güç uygulayarak bir şeyin yapısal bütünlüğüne zarar vermek' ortak anlamıyla ilişkilendirildiğine deyindik. Ayrıca, (16)'da kawaguchi de fune wo waru deyimsel ifadesinin gerçek anlamının 'uzun deniz yolculuğunu sorunsuz tamamlamanın ardından koya yaklaşırken gemiyi parçalamak' ve ikincil anlamının 'başarıya ramak kala çuvallamak] olduğunu ve bu iki anlamın [bir şeyin olmasına çok az kala başarısız olmak' ortak anlamını barındırdığını belirttik. Burada dikkat çekmek istediğimiz husus, waru gibi çokanlamlı sözcüklerin gerçek ve ikincil anlamlarını birbirine bağlayan ortak anlamın bir taslak (schema) olarak nitelendirilebileceği hususudur ${ }^{13}$; zira gerçek anlam, ortak anlama göre daha özel (sınırlandırılmış) bir anlama sahiptir. Başka bir deyişle, gerçek anlam, ortak anlamda bulunmayan anlamsal özellikler taşımaktadır. Benzer bir durum, ikincil anlam ve ortak anlam arasında da söz konusudur. Bu

13 Burada kullanılan taslak (schema) terimi Langacker (1988)'in çalışmasını temel almaktadır. Ruhdilbilim (psycholinguistics) terimlerden biri olan (frame olarak da adlandırılan) taslak, hafiza içinde organize edilmiş bilgi gruplarını ya da yapılarını temsil etmektedir (Minsky, 1985, 1986; Koyatsu ve Hoshi, 1996). Bilişsel anlambilimde ise bu terim, bir kategorinin tüm bireylerine has özellikleri taşıyan soyut biçimi ifade etmek için kullanılmaktadır (Langacker, 1988). 
tespitlerimiz doğruysa, taslakla gerçek (öntip) anlam, taslakla ikincil anlam arasında sinekdok temelli bir ilişkiden bahsetmek mümkündür. ${ }^{14}$ Peki, sinekdok temelli anlamsal genişleme sadece taslak-öntip anlam ve taslak-ikincil anlam ilişkili bölgelerde mi görülmektedir? Kısım 4.1'deki örnek (18) ait tespitlerimiz doğruysa, sinekdok temelli anlamın, taslak-öntip anlam/taslak-ikincil anlam ilişkisiyle sınırlı olmadığını söylememiz mümkündür; zira bu örneklerde görülen anlamsal değişmece, öntip anlam ve ikincil anlam arasında kurulmaktadır. ${ }^{15}$

Burada belirtmemiz gereken diğer bir husus da, (15)-(17)'deki waru sözcüğüne ait metonimi temelli anlamsal genişlemelerin, yukarıda belirttiğimiz taslak kavramıyla ilişkilendirilemeyeceği hususudur. Kısım 2.2-4.2'de, her bir eylemin öntip anlamını kullanarak söz konusu örneklerdeki anlam genişlemelerinin nasıl açıklanabileceğini gördük. Peki, söz konusu örneklere ait eylemlerin gerçek anlamlarıyla ikincil anlamları arasında yukarıda belirttiğimiz anlamda bir taslak oluşturmak mümkün müdür? Metoniminin oluşma mekanizması dikkate alındığında bunun mümkün olduğunu söylemek epey zordur; zira metonimide, metafordan farklı olarak, benzetme amacı güdülmeksizin iki nesnenin dış görünüş özellikleri arasındaki yakınlık ilişkisi veya iki kavram arasındaki düşünsel/kavramsal ilişki temel alınarak, bir nesne/kavramı belirten dilsel şekille diğer bir nesne/kavram ifade edilmeye çalışılır. Taslağın iki nesneye ya da kavrama ilişkin benzerlik (ortak yön) temel alınarak oluşturulduğu düşünüldüğünde, bu benzerliğ̈in (ortak yönün) dikkate alınmadığı metonimi de bir taslaktan söz etmek mümkün görünmemektedir.

Kowasu sözcüğünde metafor-sinekdok ve kudaku sözcüğünde de metafor temelli anlam değişmecesine rastlanmamasına karşın, bu sözcüklerin öntip anlamlarının waru sözcü̆üune ait taslak ([bir şeyin olmasına çok az kala başarısız olmak] ortak anlamı) ile uyumlu olmaları, Şekil 1'deki taslă̆ı bir üst taslak (super schema) hâline getirmektedir.

Yukarıdaki tespitlerimiz ışığında, yıkım-tahrip anlamı taşıyan Japonca eylemlere ait çoklu anlamlar arasındaki karşılıklı ilişkiyi aşağıdaki gibi şematize etmemiz mümkündür.

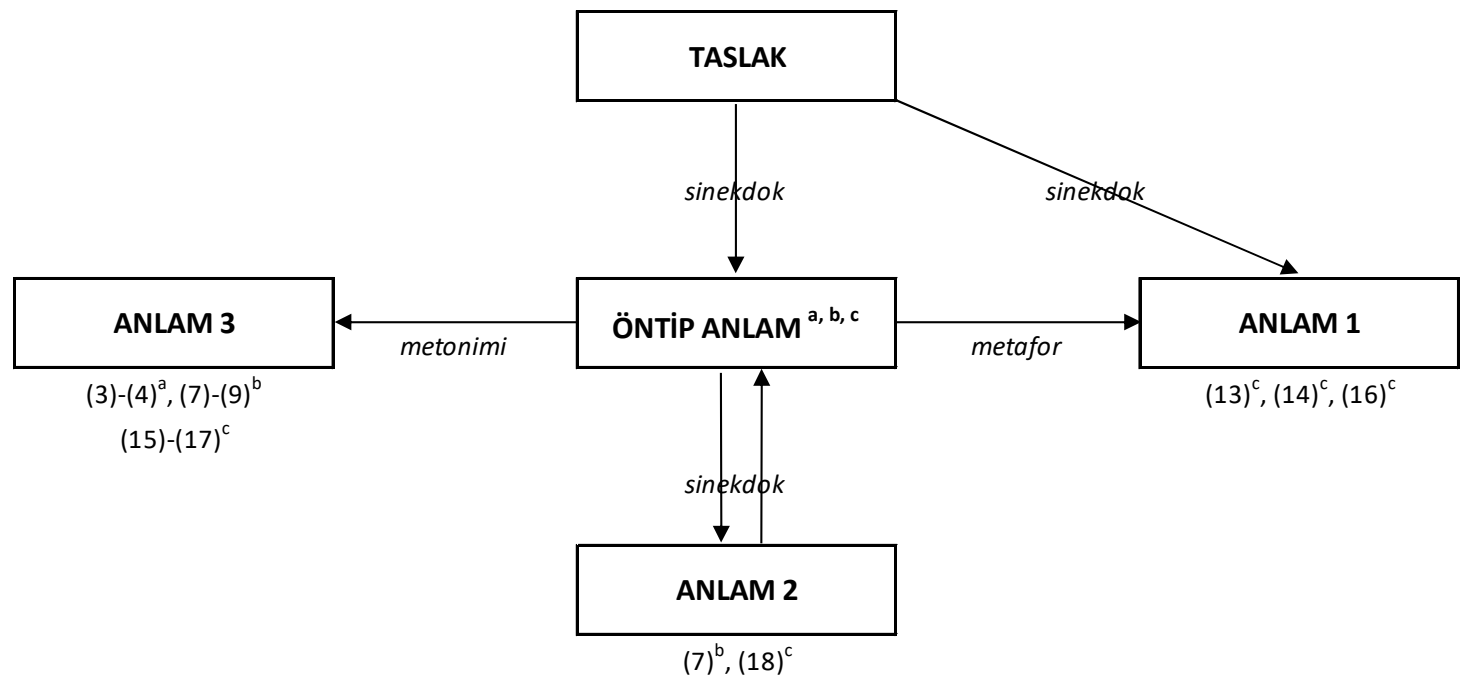

Şekil 2. Çoklu anlamlar arasındaki karşılıklı ilişki

${ }_{14}$ Benzer bir anlamsal ilisski, Machida ve Momiyama (2002, s. 112-117)'de Japonca adlar ve i-sıfatları için rapor edilmektedir.
${ }_{15}$ Waru'nun tümce (18)'deki kullanımı da dikkate alındığında, (16)'daki taslağın (13)-(14)'deki taslağa göre daha bölgesel Waru'nun tümce (18)'deki kullanımı da
(local) olduğunu söylemek mümkündür. 
Şekil 2'deki, ANLAM 1/2/3, bir eyleme ait ikincil anlamları; oklar, anlam genişlemesini ve yönünü; a/b/c üst simgeleri, sırasıyla, kowasu-kudaku-waru sözcüklerini; parantez içideki numaralar Bölüm 2-4'deki örnek tümce numaralarını temsil etmektedir.

\section{Sonuç}

Bu çalışmada, yakın anlamlı sözcüklerin birbirine benzer ve birbirinden farklı anlamsal özelliklerinin nasıl belirleneceği, bu sözcüklerin öntip anlamları ile çoklu anlamları arasındaki karşılıklı ilişkilerin nasıl tesis edileceği hususlarına, yıkım-tahrip anlamı taşıyan kowasu, kudaku ve waru Japonca yakın anlamlı eylemleri aracılığıyla ışı tutulmaya çalışılmıştır. Bölüm 2, 3 ve 4'de, sırasıyla kowasu, kudaku ve waru eylemlerine ait çoklu anlamlar belirlenerek (Kısım 2.1-4.1) bunlara ait öntip anlamlar tanımlanmış ve öntip anlam kapsamı dışında kalan kullanımlardaki anlam genişlemeleri tespit edilmiştir (Kısım 2.2-4.2). Araştırmamızın bulguları bize, kowasu sözcüğünde metonimi, kudaku sözcüğünde metonimi-sinekdok ve waru sözcüğünde metafor-metonimi-sinekdok temelli anlamsal genişlemeler olduğunu ve bu anlamsal genişlemelerin ilgili eylemin öntip anlamı kullanılarak açıklanabileceğini göstermiştir. Bölüm 5'de, kowasu-kudaku-waru sözcüklerinin öntip anlamları arasındaki karşllıklı ilişkiler irdelenmiştir. Kudaku sözcüğünün öntip anlamının waru sözcüğünün öntip anlamını kapsar nitelikte olduğu vurgulanmış ve kudaku-waru eylemlerinin işlevsel parçalardan oluşmuş nesneleri belirten sözcüklerle de kullanılabilmeleri bu eylemlerin öntip anlamlarını kowasu sözcüğünün anlam alanına yaklaştırdığı hususu üzerinde durulmuştur. Bölüm 6'da, çoklu anlamlar arasındaki karşıllklı ilişkiler üzerinde durulmuştur. Sinekdok temelli anlamsal genişlemenin, söz konusu eyleme ait taslak-öntip anlam ve taslak-ikincil anlam arasındaki ilişkilerle sınırlı olmayı, öntip anlam ve ikincil anlam arasındaki karşılıklı ilişkileri de kapsadığı hususuna vurgu yapılmıştır.

Çalışma, Japon diline ilişkin özellikli bir konuyu irdelemesine karşın, bulguları, yakın anlamlı sözcüklerin çok yönlü doğası hakkında genel bir görüş elde etmemize imkân sağlayacak niteliktedir. Çalışmaya ait yöntem ve sonuçların, bilişsel dilbilim, sözlükbilim, dil edimini ve yabancı dil eğitimi gibi alanlardaki çalışmalara sağlayacağı katkılar açısından dikkate değer olduğu kanısındayız.

\section{Kaynakça}

Aksan, D. (2000). Her Yönüyle Dil, Ana Çizgileriyle Dilbilim, 1. Cilt. Ankara: Türk Dil Kurumu.

Aksan, D. (2004). Eşanlamlılık Sorunu ve Türk Yazı Dilinin Eskiliğinde Eşanlamlılardan Yararlanma. Aksan, D. (Yay. Haz.), Dilbilim ve Türkçe Yazıları, s. 157-185. İstanbul: Multilingual Yabancı Dil.

Bloomfield, L. (1933). Language. New York: Henry Holt.

Bussmann, H. (1996). Routledge Dictionary of Language and Linguistics. London and New York: Routledge.

Croft, W. ve Cruse, D. A. (2004). Cognitive Linguistics. Cambridge: Cambridge University Press.

Çankaya, B. (1996). Japonca Cep Sözlüğ̈̈. İstanbul: Fono.

Demirci, M. (1999). Japonca-Türkçe Sözlük. İstanbul: Japon Kültür ve Enformasyon Merkezi.

Duman, M. A. (2015). Dilde Belirsizlik ve Eş Anlamlılık. İstanbul: Litera.

Ersoylu, H. (2001). Eş Anlamlılık mı, Yabancı Kaynaklı Karşılık Oluş mu? Türk Dili, 59, 250-266.

Geeraerts, D. (Yay. Haz.) (2006). Cognitive Linguistics: Basic Readings. Berlin: Mouton de Gruyter.

Gündoğdu, A. E. (2019). Türkçede Yakın Anlamlılık Olgusu: "Geniş" ve "Bol" Sifatları Üzerine Bir Değerlendirme. Pamukkale Üniversitesi Sosyal Bilimler Enstitüsü Dergisi, 34, 39-46.

Hatiboğlu, V. (1970). Eş Anlamlı Sözcükler Var mıdır? Türk Dili Dergisi, 229, 9-10. 
İmer, K., Kocaman, A. ve Özsoy, A. S. (2011). Dilbilim Sözlüğü. İstanbul: Boğaziçi Üniversitesi.

Jackendoff, R. (1983) Semantics and Cognition. Cambridge, Massachusetts: MIT Press.

Kinsui, S. ve Imani, I. (2008). Imi to Bunmyaku - Gendai Gengogaku Nyūmon 4 [Anlam ve Bağlam Modern Dilbilime Giriş 4]. Tōkyō: Iwanami Shoten.

Kitahara, Y. (2010). Meikyō Kokugo Jiten [Bilgisayar Yazılımı]. Tōkyō: Daishū Shoten.

Konichi, T. ve Minami, D. (2006). Jiniasu Eiawa (Sürüm 4.o) Waei Jiten (Sürüm 2.0) [Bilgisayar Yazılımı]. Tōkyō: Logo Vista.

Koyatsu, T. ve Hoshi, K. (1996). Ninchi Shinrigaku [Bilişsel Psikoloji]. Tōkyō: Hōsō Daigaku Kyōiku Shinkōkai.

Langacker, R. W. (1988). A View of Linguistic Semantics. Brygida Rudzka-Ostyn (Yay. Haz.), Topics in Cognitive Linguistics, s. 49-90. John Benjamins Publishing Company.

Langacker, R. W. (2009). Investigations in Cognitive Grammar. Berlin, New York: Mouton de Gruyter.

Machida, K. ve Momiyama, Y. (2002). Ninchi Imiron no Shikumi [Bilişsel Anlambilimin Mekanizması]. Tōkyō: Kenkyūsha.

Matsumura, A. (1999). Sūpā Daijirin (Sürüm 3.o) [Bilgisayar Yazılımı]. Tōkyō: Sanseidō.

Minsky, M. (1985, 1986). The Society of Mind. New York: Simon \& Schuster.

Palmer, F. R. (1981). Semantics. Cambridge: Cambridge University Press.

Sarı, M. (2011). Türkiye Türkçesinde Eș Anlamlılıkla İlgili Bazı Sorunlar. Turkish Studies, 6(1), 523-528.

Shinmura, I. (2008). Kōjien (Sürüm 6.0) [Bilgisayar Yazılımı]. Tōkyō: Logo Vista.

Takeuchi, K. (1996). Torukogo Jiten [Türkçe-Japonca Sözlük]. Tōkyō: Daigaku Shorin.

Talmy, L. (2000). Toward a Cognitive Semantics, Volume I: Concept Structuring Systems. Cambridge, Massachusetts: MIT Press.

Tekin, T. (1997). Türkoloji Eleştirileri. Ankara: Simurg.

Uçar, A. (2009). Türkçe Eylemlerde Çokanlamlılı: Uygunluk Kuramı Çerçevesinde Bir Çözümleme (Doktora tezi). Ankara Üniversitesi Sosyal Bilimler Enstitüsü, Ankara, Türkiye.

Yamashita, S. (1992). Japonca-Türkçe Türkçe-Japonca Sözlük. Aichi: Kendi Yayını. 